\title{
Kasabach-Merritt syndrome: clinical vs. surgical treatment
}

\author{
Síndrome de Kasabach-Merritt: tratamento clínico versus cirúrgico
}

Regina Moura', Marcone Lima Sobreira', Matheus Bertanha', Rodrigo Gibin Jaldin', Maria Madalena Silva', Lied Pereira', Bonifacio Katsunori Takegawa', Winston Bonetti Yoshida

\begin{abstract}
Kassabach-Merritt syndrome is a combination of capillary hemangioma and thrombocytopenia that predisposes to bleeding with petechiae, ecchymosis and spontaneous bruising. Treatment is generally started with corticosteroids, interferon al pha or chemotherapy. We present the case of a child (aged 1 year and 9 months) with a giant hemangioma, from the root of the thigh to the knee, and thrombocytopenia. Treatment was started with corticosteroids, without improvement, and then intra-tumor and cutaneous bleeding appeared spontaneously. The patient's clinical condition precluded prescription of vincristine and interferon and emergency tumor resection was conducted because of extreme thrombocytopenia and bleeding. The child then began to develop sepsis with hypotension and ischemia of remnant tissues. This case presented a therapeutic challenge, which is the subject of this article.
\end{abstract}

Keywords: Kasabach-Merritt syndrome; amputation; corticosteroids; hemangioma.

\section{Resumo}

A síndrome de Kassabach-Merritt é uma associação de hemangioma capilar e trombocitopenia, que promove sangramentos com petéquias, equimoses e hematomas espontâneos. A conduta é tratar com corticoide, interferon alfa ou quimioterápicos. Apresentamos um caso de criança (com 1 ano e 9 meses anos de idade) com um hemangioma gigante desde a raiz da coxa até altura do joelho, e plaquetopenia. O tratamento foi iniciado com corticoterapia sem melhora do quadro, surgindo de forma espontânea pontos de sangramento intratumoral e cutâneo. Sem condições clínicas de receber vincristina e o interferon, foi feita a ressecção tumoral de urgência por extrema plaquetopenia e sangramento. A criança começou então a desenvolver um quadro séptico com hipotensão e isquemia do tecido residual. Diante deste quadro, configurou-se um desafio terapêutico que será objeto deste artigo.

Palavras-chave: Síndrome de Kasabach-Merritt; amputação; corticoides; hemangioma. 


\section{INTRODUCTION}

Hemangiomas are congenital lesions that are common in newborn infants and children. They are generally benign and often resolve spontaneously. However, in 3 to $5 \%$ of cases, they can cause complications inherent to their size, to involvement of vital organs and to the concomitant coagulopathy. ${ }^{1}$ Kassabach-Merritt syndrome is a combination of capillary hemangioma and thrombocytopenia, manifesting with hard tumors that cause bleeding and petechiae, ecchymosis and spontaneous bruising. ${ }^{2}$ The condition comprises large hemangiomas, or hemangioendotheliomas, that must be treated because of the associated platelet disorders and bleeding problems, which cause severe anemias and can result in death. ${ }^{3}$ Platelets are activated and there is secondary consumption of coagulation factors. This continuous consumption of platelets and coagulation factors, and also stimulation of fibrinolysis, result in intratumoral bleeding causing major tumor growth and maintaining the vicious circle. Occasionally intratumoral clots forms, which are partially responsible for the small number of spontaneous remissions from bleeding that have been observed. ${ }^{3}$

The objective of this CHALLENGE is to illustrate the course of a case in which conventional clinical treatments did not lead to patient improvement, making it necessary to find alternative options.

\section{PART I - THE SITUATION}

The patient was a female newborn child with a giant hemangioma running from the root of the thigh to the level of the knee (Figure 1) and thrombocytopenia $\left(58,000 / \mathrm{mm}^{3}\right)$. She was initially treated with corticoid therapy $(4 \mathrm{mg} / \mathrm{Kg} /$ day of prednisone) and her platelet count returned to normal $\left(100,000 / \mathrm{mm}^{3}\right)$. She was discharged in good clinical condition and kept on the corticoid for 4 months. During this period she suffered several airway infections and the hemangioma began to exhibit signs of regression, with areas of blanching in the central region. It was necessary to suspend corticoid therapy because of the repeated infections and the hemangioma began to exhibit signs of worsening, with bleeding inside the tumor and low platelet counts. At this point, a cardiological assessment was conducted and propranolol was prescribed $(2 \mathrm{mg} / \mathrm{kg}$ ).

While on propranolol the child exhibited hypotension and hypoglycemia, forcing withdrawal of the drug.

She was submitted to elastic compression, with bandage of the thigh, during the treatment. A duplex scan was performed and revealed dilated veins in the muscles at the site of the hemangioma, no signs of arteriovenous fistulas and a normal deep vein system (Figure 2). Magnetic resonance imaging was also performed and revealed the extent of the lesion (Figure 3).

At the age of 1 year and 9 months, the lesion began to grow once more and the child suffered a drop in platelet counts to between 38,000 and $58,000 / \mathrm{mm}^{3}$, and at this point the cutaneous lesions started intermittent and low volume bleeding. Laboratory tests were requested, with the following results: D-dimer $=5000 \mathrm{ug} / \mathrm{L}$; fibrinogen $=30 \mathrm{mg} / \mathrm{dL}$; and mild anemia $(\mathrm{Hb}=29.5 \% ; \mathrm{Hb}=9.6 \mathrm{~g} / \mathrm{dL}$ and $\mathrm{RBC}$ $=2.81 \mathrm{million} / \mathrm{mm}^{3}$ ).

The decision was taken to employ corticoid therapy once more, but the patient's condition did not improve. The hemangiomatous tumor began to harden, platelet counts dropped further still $\left(32,000 / \mathrm{mm}^{3}\right)$ and the anemia worsened. Additionally, some of the more fragile areas of the skin began to rupture spontaneously, with continuous bleeding of

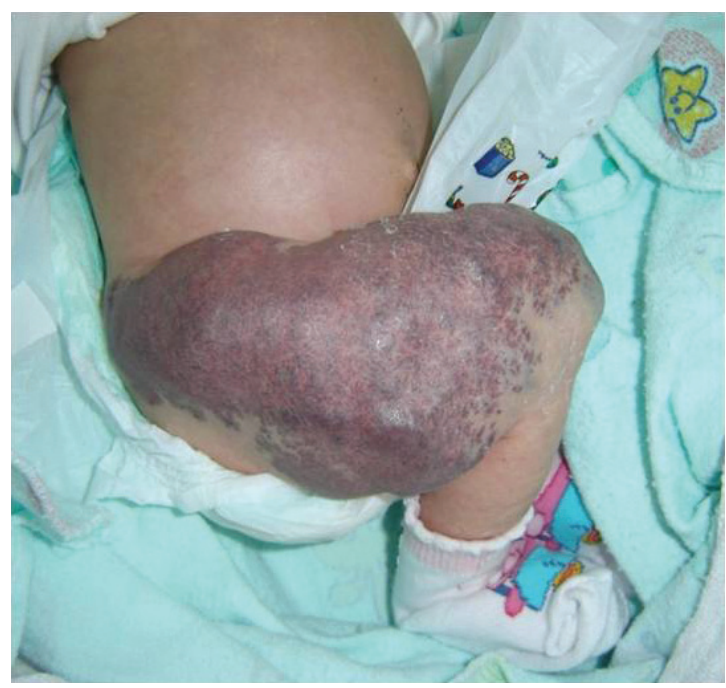

Figure 1. Hemangiomatous lesion in the right thigh.

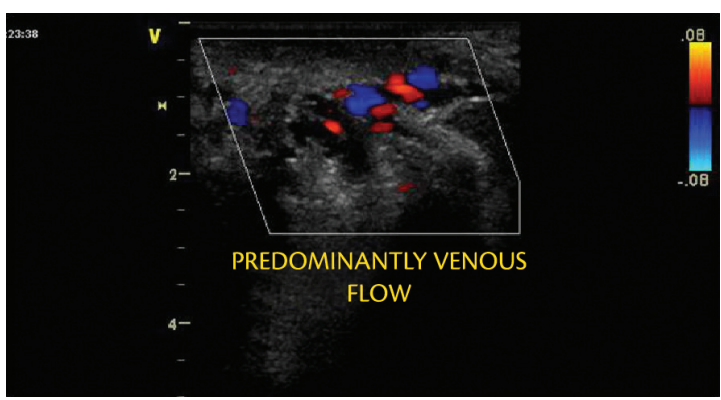

Figure 2. Duplex scan showing venous flow inside the lesion. 


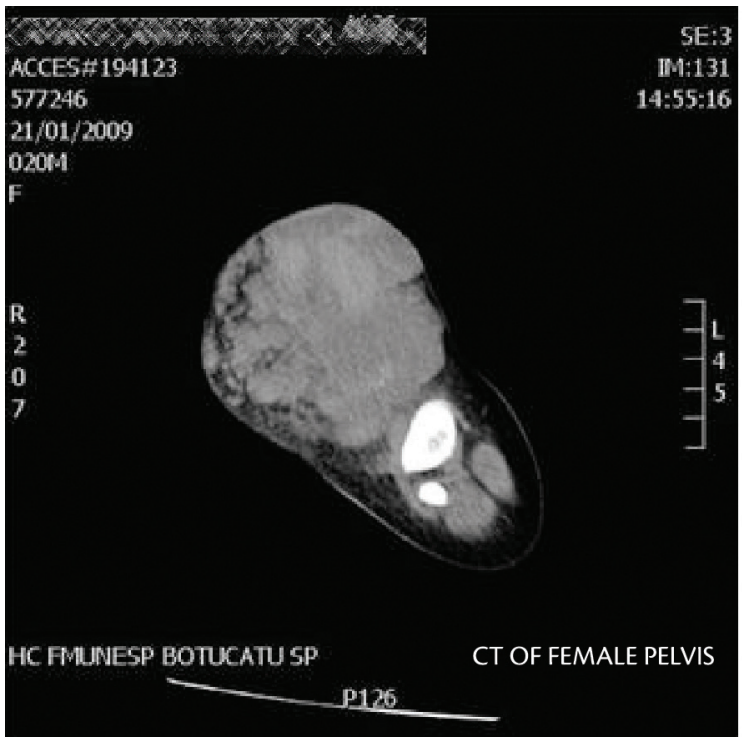

Figure 3. Magnetic resonance images showing lesions.

the skin. The child was admitted to hospital with hypovolemia and prescribed blood replacement. She was also treated with plasminogen, but there was no improvement. She continued to suffer successive spontaneous bleeding from the tumor and her platelet count remained around $38000 / \mathrm{mm}^{3}$, with hematocrit at $31.6 \%$ and fibrinogen at $39.4 \mathrm{mg} / \mathrm{dL}$.

At this point, treatment options were as follows: maintain compression; prednisolone; alpha-interferon; vincristine, cyclophosphamide; antifibrinolytic or antiplatelet drugs, localized radiotherapy and embolizations, or tumor resection surgery.

\section{PART II - WHAT WAS DONE}

While in hospital, the child suffered a varicella infection ruling out treatment with all of the drugs listed above, including the chemotherapy drugs (interferon-alpha and vincristine, or others). In order to control the foci of bleeding, attempts were made to achieve hemostasis of the hemangioma with several stitches, but these attempts were unsuccessful because the bleeding was already in jets and of large volume, characterizing a very severe state of localized hypertension. Each time a source of bleeding was stitched, new foci emerged and the method proved unable to deliver a definitive solution.

The patient was given fresh plasma, cryoprecipitates, platelets, antifibrinolytics (tranexamic acid-transamin) and concentrated red blood cells, without success.

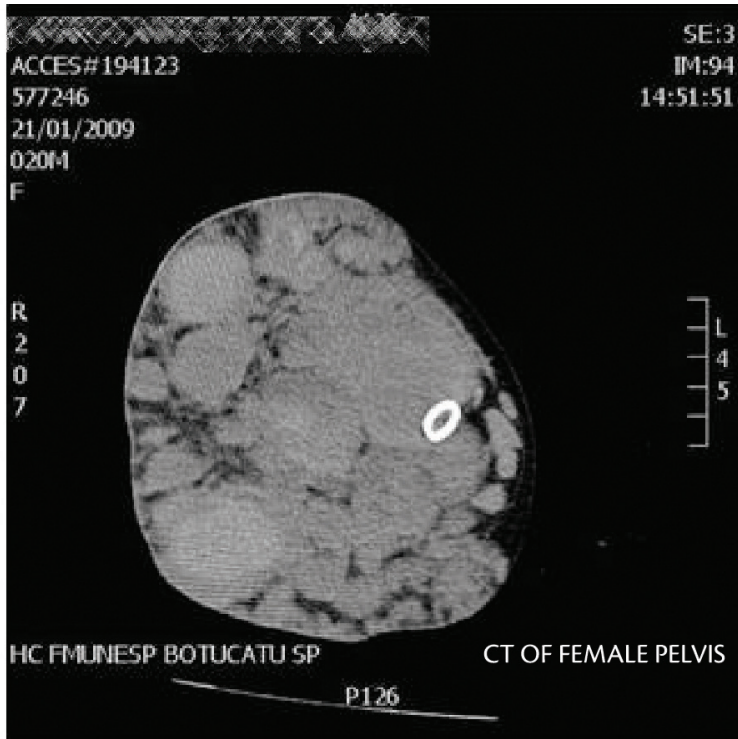

After these unsuccessful attempts to reduce consumption of platelets and bleeding and in view of the gravity of the situation, with extreme thrombocytopenia $\left(23,000 / \mathrm{mm}^{3}\right)$ and bleeding, the decision was taken to conduct emergency tumor resection.

The resection was large, with removal of skin, subcutaneous tissues and a considerable quantity of the musculature, and little tissue with visible vascular malformations remained. It was not initially possible to close the skin. For 4 days, attempts were made to dress the exposed tissues, but the child began to exhibit signs of sepsis with hypotension and ischemia of the remaining tissues. In view of the gravity of this clinical status, the decision was taken to amputate the limb with disarticulation at the level of the groin.

The pathology results were compatible with giant cavernous hemangioma, with an area of recent thrombosis and concomitant lymphangioma, which, in combination with the clinical data, were suggestive of Kasabach Merritt syndrome. The child progressed well during immediate follow-up and the surgical wound healed (Figure 4). Platelet counts returned to normal and hematocrit levels recovered. Over the longer term, one year later the child was still progressing well clinically, had been fitted with a prosthesis and was attending a rehabilitation program (Figure 5). She recently suffered a relapse of the lesion at the amputation scar and is receiving successful laser treatment. The lesions at the incisions regressed and she is adapting to her prosthesis. 


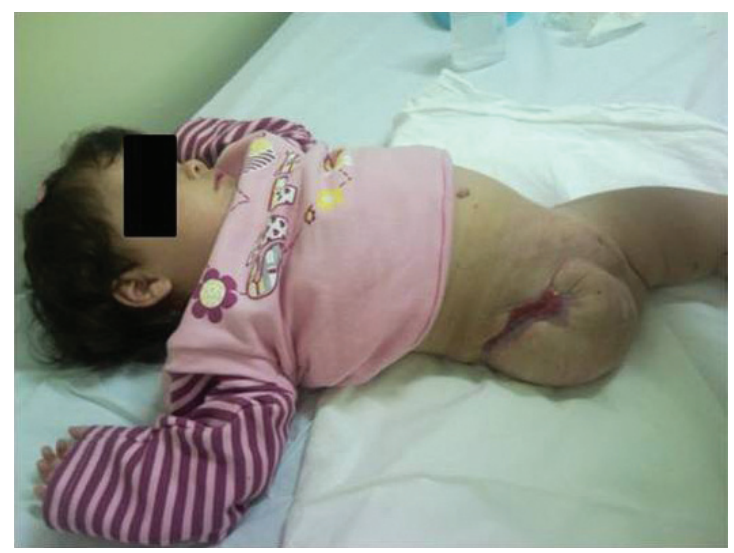

Figure 4. Post-amputation, already in healing phase.

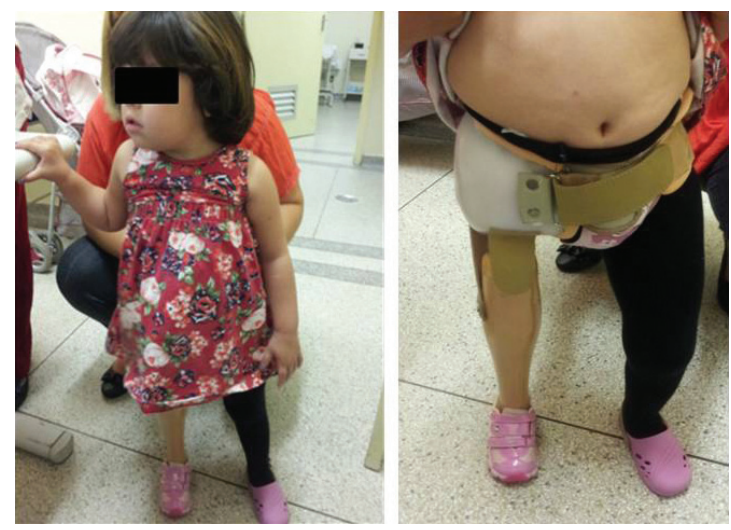

Figure 5. During rehabilitation with prosthesis phase.

\section{DISCUSSION}

Kasabach-Merrit syndrome is not a common complication of the hemangiomatoses and so few articles have been published about treatment of the syndrome and those recommendations that do exist are based on case reports or small case series. ${ }^{4}$

Diagnosis should be based on clinical manifestations, with presence of hemangiomatosis combined with profound thrombocytopenia and consumption coagulopathy. Thrombocytopenia tends to reach extreme lows $(<20 \times 109$ platelets per liter). Consumption coagulopathy can be confirmed by the presence of hypofibrinogenemia and by detecting the products of fibrin breakdown (D-dimer), which is why in this case it was decided to monitor changes in D-dimer levels to indicate the severity of this process during clinical treatment. Once the tumor had been removed, it was no longer necessary to continue this monitoring. Diagnosis should be confirmed with a combination of imaging exams and histology of the hemangiomatous lesion. ${ }^{3}$ Ultrasound, computed tomography, magnetic resonance and digital angiography are also important diagnostic tools.

Compression treatment with bandages or intermittent pneumatic compression has been recommended as a coadjuvant therapy ${ }^{5,6}$ particularly for lesions located in extremities, but in the case of Kasabach-Merrit syndrome, the hemangiomatous lesion can be painful or tense or may not be compressible. Coadjuvant radiotherapy can be effective, but can lead to shortened limbs over the long term. ${ }^{7}$

It is recommended that compensation for the losses of blood and coagulation factors should be attempted using fresh plasma $(15 \mathrm{~mL} / \mathrm{kg})$, cryoprecipitate $(5-10$ $\mathrm{mL} / \mathrm{kg}$ ) and concentrated platelets $(10-15 \mathrm{~mL} / \mathrm{kg})$. Blood replacement should proceed with caution to avoid cardiac overload. ${ }^{3}$

It is recommended that resection or embolization of the hemangioma should be the primary approach whenever this is possible and feasible. ${ }^{3,8}$ However, since hemangiomatous lesions are generally very extensive or diffuse, this option is often not available. Embolization or sclerotherapy are highrisk procedures in this case, because in a number of unsuccessful attempts the result has been to enlarge openings in the skin and worsen the bleeding.

The first line clinical treatment is corticoids (steroids). Prednisolone is recommended at a dosage of 2-3 mg/kg/day. ${ }^{8}$ Around one third of patients do not respond to this first dosage and higher doses can be given at the pediatric oncologist's discretion. ${ }^{3,8}$

Alpha-interferon acts as an antiangiogenic and antiproliferative agent. ${ }^{9}$ Around one half of patients tend to respond well to this treatment, ${ }^{10}$ but because of the risk of spastic diplegia linked with long-term treatment, it should only be prescribed for short periods and in cases in which there is a risk of loss of life. ${ }^{3}$

In extreme cases chemotherapy with vincristine, ${ }^{11-15}$ cyclophosphamide and/or actinomycin is an option and should be monitored by a specialist in pediatric oncology.

Administration of anticoagulants is controversial and antiplatelet drugs are even more doubtful. In the case described here, anticoagulants of whatever type would have been inappropriate because the patient had severe thrombocytopenia and was on constant blood replacement, due to continuous bleeding from the lesion. In different circumstances, KasabachMerrit syndrome has been successfully treated with ticlopidine and pentoxifylline, but there was no bleeding in those cases. ${ }^{8}$ When hypofibrinogenemia is the most important component of the coagulopathy, 
antifibrinolytics such as tranexamic acid and epsilon aminocaproic acid may be indicated..$^{16,17}$

In the case described here, several different attempts to control the coagulopathy, bleeding and anemia were fruitless and there was no other option than to resection the hemangioma, followed by amputation of the limb as a final option to save the child.

Despite the mutilation, she progressed well, going through a successful process of rehabilitation, with social and affective integration.

\section{CONCLUSIONS}

Clinical treatment of these anomalies does not always have satisfactory results and sometimes the aggressive and invasive option of resection of the hemangiomatous tumor is the only solution that can save these patients.

\section{REFERENCES}

1. Hoeger PH, Helmke K, Winkler K. Chronic consumption coagulopathy due to an occult splenic haemangioma: KasabachMerritt syndrome. Eur J Pediatr. 1995;154(5):365-8. http://dx.doi. org/10.1007/BF02072104. PMid:7641767

2. Kasabach HH, Merrit KK. Capillary hemangioma with extensive purpura. Am J Dis Child. 1940;59(5):1063-70. http://dx.doi. org/10.1001/archpedi.1940.01990160135009.

3. Hall GW. Kasabach-Merritt syndrome: pathogenesis and management. Br J Haematol. 2001;112(4):851-62. http://dx.doi. org/10.1046/j.1365-2141.2001.02453.x. PMid:11298580

4. el-Dessouky M, Azmy AF, Raine PA, Young DG. Kasabach-Merritt syndrome. J Pediatr Surg. 1988;23(2):109-11. http://dx.doi. org/10.1016/S0022-3468(88)80135-0. PMid:3278084

5. Drolet BA, Esterly NB, Frieden IJ. Hemangiomas in children. N Engl J Med. 1999;341(3):173-81. http://dx.doi.org/10.1056/ NEJM199907153410307. PMid:10403856
6. Sarihan H, Mocan H, Abeys M, Akyazici R, Cay A, Imamoğlu $M$. Kasabach-Merrit syndrome in infants. Panminerva Med. 1998;40(2):128-31. PMid:9689834.

7. Mitsuhashi N, Furuta M, Sakurai H, et al. Outcome of radiation therapy for patients with Kasabach-Merritt syndrome. Int J Radiat Oncol Biol Phys. 1997;39(2):467-73. http://dx.doi.org/10.1016/ S0360-3016(97)00140-5. PMid:9308952

8. Enjolras O, Wassef $M$, Dosquet $C$, et al. Syndrome de KasabachMerritt sur angiome en touffes congénital. Ann Dermatol Venereol. 1998;125(4):257-60. PMid:9747263.

9. Bustos Betanzo R, Campos Cerda L. [The use of interferon alfa in Kasabach-Merrit Syndrome]. An Esp Pediatr. 2002;56(6):5823. http://dx.doi.org/10.1016/S1695-4033(02)77870-3. PMid:12042159

10. Chang E, Boyd A, Nelson CC, et al. Successful treatment of infantile hemangiomas with interferon-alpha-2b. J Pediatr Hematol Oncol. 1997;19(3):237-44. http://dx.doi.org/10.1097/00043426199705000-00011. PMid:9201147

11. Canatan D, Aydın MA, Kuybulu AE, Boyacı A, Koca T. Successful use of vincristine in the management of Kasabach-Merritt Phenomenon. S.D.Ü. Týp Fak. Derg. 2012;19(2):55-58.

12. Fawcett SL, Grant I, Hall PN, Kelsall AW, Nicholson JC. Vincristine as a treatment for a large haemangioma threatening vital functions. Br J Plast Surg. 2004;57(2):168-71. http://dx.doi. org/10.1016/j.bjps.2003.11.003. PMid:15037175

13. Fernandez-Pineda I, Lopez-Gutierrez JC, Ramirez G, Marquez C. Vincristine-ticlopidine-aspirin: an effective therapy in children with Kasabach-Merritt phenomenon associated with vascular tumors. Pediatr Hematol Oncol. 2010;27(8):641-5. http://dx.doi. org/10.3109/08880018.2010.508299. PMid:20863161

14. Traivaree C, Lumkul R, Torcharus K, Krutuecho T, Sriphaisal T. Outcome of Kasabach-Merritt phenomenon: the role of vincristine as monotherapy: report of a case. J Med Assoc Thai. 2012;95(Suppl 5):S181-5. PMid:22934467.

15. Watanabe $Y$, Onuma $M$, Looi $C Y$, et al. Vincristine-resistant Kasabach-Merritt phenomenon successfully treated with lowdose radiotherapy. Int J Hematol. 2011;93(1):126-8. http://dx.doi. org/10.1007/s12185-010-0740-4. PMid:21161618

16. Colvin BT. Management of disseminated intravascular coagulation. Br J Haematol. 1998;101(Suppl 1):15-7. PMid:9607737.

17. Cabrera, HN; Savoia, J; Dibar, E; Boffi, A. Sindrome de KasabachMerrit (Tumor vascular trombocitopeniante). Rev Argent Dermatol. 1981, 62:177-81. 
Correspondence

Regina Moura

Departamento de Cirurgia e Ortopedia, Faculdade de Medicina de Botucatu, Universidade Estadual Paulista (UNESP), Campus de

Botucatu

Distrito de Rubião Júnior, $\mathrm{s} / \mathrm{n}$ CEP 18618-000 - Botucatu (SP), Brazil Tel.: +55 (14) 3815.7428

E-mail: rmoura@fmb.unesp.br

Author information

RM is a PhD, assistant professor of the Discipline of Vascular and Endovascular Surgery, Faculdade de Medicina de Botucatu, Universidade Estadual Paulista (UNESP), and Head of the Vascular Malformation Outpatient Clinic, Botucatu-SP, Brazil.

MLS is an assistant professor of the Discipline of Vascular and Endovascular Surgery, Faculdade de Medicina de Botucatu, Universidade Estadual Paulista (UNESP), Botucatu-SP, Brazil.

$M B$ is an assistant professor of the Discipline of Vascular and

Endovascular Surgery, Faculdade de Medicina de Botucatu,

Universidade Estadual Paulista (UNESP), Botucatu-SP, Brazil.

RG) is Board certified in Vascular Surgery, Angioradiology, Endovascular Surgery, and Doppler Vascular Ultrasound, is a vascular and endovascular surgeon at Hospital das Clínicas de Botucatu,

Universidade Estadual Paulista (UNESP), Botucatu-SP, Brazil. MMS is an assistant professor of the Discipline of Plastic Surgery, Faculdade de Medicina de Botucatu, Universidade Estadual Paulista (UNESP), Botucatu-SP, Brazil.

$L P$ is a physician and head of the Pediatric Oncology Service at Hospital das Clínicas da UNESP, Botucatu-SP, Brazil. BKT is a PhD, assistant professor of Pediatric Surgery at Universidade Estadual Paulista (UNESP), Botucatu-SP, Brazil.

WBY is a full professor of Vascular and Endovascular Surgery at Faculdade de Medicina de Botucatu, Universidade Estadual Paulista (UNESP), Botucatu-SP, Brazil.

Author contributions Conception and design: RM Analysis and interpretation: RM, RG) Data collection: BKT, MMS, LP, MLS

Writing the article: RM. WBY. MB Critical revision of the article: RGJ, WBY Final approval of the article*: RM

Statistical analysis: N/A

Overall responsibility: RM

*All authors have read and approved of the final version of the article submitted to I Vasc Bras. 